\title{
Dynamics of microphytobenthos biomass in the Ems estuary
}

\author{
V. N. de Jonge ${ }^{1}$, F. Colijn ${ }^{2}$ \\ ${ }^{1}$ National Institute for Coastal and Marine Management, PO Box 207, 9750 AE Haren (Gn), The Netherlands \\ ${ }^{2}$ National Institute for Coastal and Marine Management, PO Box 20907, 2500 EX Den Haag, The Netherlands
}

\begin{abstract}
The temporal dynamics of benthic chlorophyll a (chl a) in the Ems estuary (The Netherlands. NW Europe) were studied over ca 3 yr at 6 stations. The mean annual concentrations of chl $a$ ranged from 28.6 to $247.0 \mathrm{mg} \mathrm{m}^{-2}$ in the top $0.5 \mathrm{~cm}$ of sediment. The relative vertical distribution of $\mathrm{chl} a$ in the sediment revealed a profile which was similar for 5 of the 6 stations. This distribution of $\mathrm{chl} a$, representing vital cells, was reconstructed from typical vertical distributions of chl $a$ including the derivatives with an absorption peak at the same wavelength. The graphs were converted and used to calculate the total biomass of the microphytobenthos expressed as organic carbon. The lowest value of the mean annual biomass of microphytobenthos per station was $3.1 \mathrm{~g} \mathrm{C} \mathrm{m}^{-2}$, and the highest was $16.7 \mathrm{~g} \mathrm{C} \mathrm{m}^{-2}$ Average values over the total period investigated ranged from 3.2 to $11.0 \mathrm{~g} \mathrm{C} \mathrm{m}^{-2}$. With one exception where a value of 0.6 was calculated, the ratio between the biomass from the 0.5 to $2.0 \mathrm{~cm}$ sediment layer and that from the 0 to $2 \mathrm{~cm}$ sediment layer was fairly constant $(0.40$ to 0.47 ). This illustrates that sampling only the top $0.5 \mathrm{~cm}$ of the sediment to determine the microphytobenthos chl $a$ and multiplying this value by the corresponding $\mathrm{C} / \mathrm{chl}$ a ratio results in the carbon biomass being grossly $(40$ to $60 \%)$ underestimated. The use of an incorrect $\mathrm{C} / \mathrm{chl}$ a ratio (which varied between 40 and 61 during the study period) in this calculation can increase this deviation by a further $50 \%$.
\end{abstract}

KEY WORDS: Microphytobenthos biomass - Chlorophyll a Carbon - Carbon to chlorophyll a ratio $(\mathrm{C} / \mathrm{chl}$ a) $\cdot$ Ems estuary Abiotic conditions

\section{INTRODUCTION}

In estuaries such as that of the Ems (The Netherlands) phytoplankton and microphytobenthos are the main primary producers. This microphytobenthos consists mainly of benthic diatoms. Measurements of primary production in the water column of the Ems estuary (Colijn 1983) and on the intertidal flats (Colijn \& de Jonge 1984) have shown the contribution made by both to the total primary production; the contribution of resuspended microphytobenthos to the total phytoplankton in the Ems estuary was reported by de Jonge \& van Beusekom (1992).

The relative importance of phytoplankton and microphytobenthos varies along the estuary. In the lower reaches, between the barrier islands and the mainland, primary production in the water column is more important than benthic primary production, due to the low turbidity of the water. In the upper reaches
(Dollard and lower Ems) the opposite is true. Altogether the benthic primary production accounts for ca $20 \%$ of the total production (including the production of excretion products) (Colijn 1983). However, another $25 \%$ is attributable to resuspended microphytobenthos (de Jonge in press). In order to determine the relationships between grazers and benthic algae it is not sufficient to know the production values (Ludden et al. 1985). The grazing efficiency of zooplankton, nematodes, harpacticoid copepods, filter feeding bivalves, etc., depends on the concentration of food relative to the density of the grazers (Admiraal et al. 1988, de Jonge \& van Beusekom 1992). To calculate this concentration of food, the algal biomass has to be determined.

There are several different ways of determining algal biomass. These techniques usually involve either cell counting, followed by conversion to biovolume or organic carbon (Mullin et al. 1966, Strathmann 1967), 


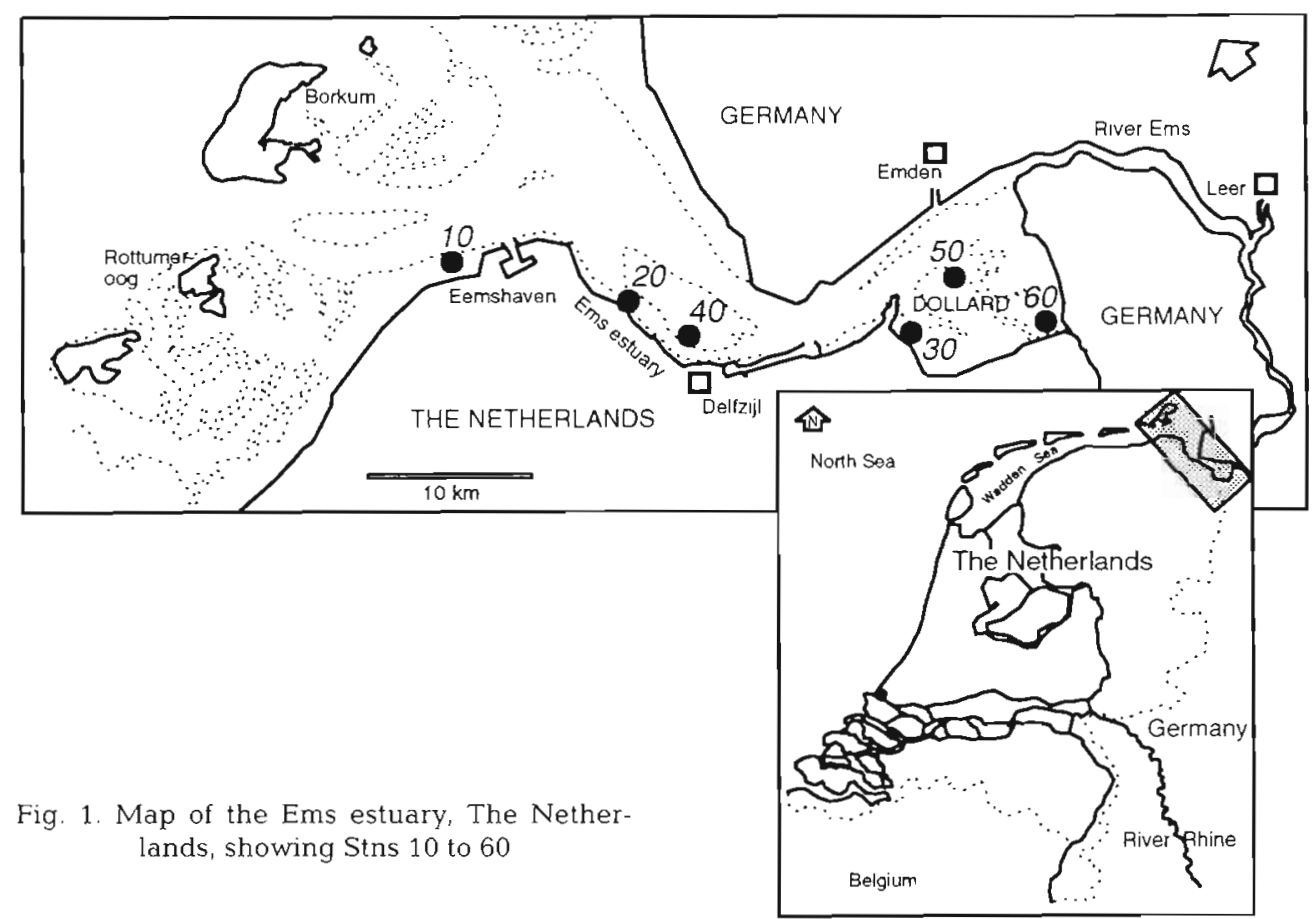

or calculations using concentrations of chlorophyll a (chl a) and organic carbon (Banse 1977 ), or ${ }^{14} \mathrm{C}$ labelling of chl a (Redalje \& Laws 1981, Redalje 1983). All these techniques have their limitations. The method developed by Banse (1977) cannot be applied to sediment-inhabiting algae in the Ems estuary because the living algae represent only a very small fraction of the total organic carbon (de Jonge 1979). Until very recently (Gould \& Gallagher 1990) labelling of chl $a$ with ${ }^{14} \mathrm{C}$ to determine microphytobenthos biomass was little used. For calculation of assimilation numbers $\left(P_{\text {max }}^{\mathrm{B}}\right)$ and for comparisons between areas, a biomass parameter, chl $a_{1}$ is often used. This is done because this pigment is simple to measure.

However, without additional information from the field, measured on the same populations, neither cell counts nor chl a measurements can be used as an adequate estimate for algal biomass. This is simply because chl a content varies per cell, per cell volume, per unit of organic carbon and per date.

A technique to determine the seasonal variations in the $\mathrm{C} / \mathrm{chl}$ a ratio for benthic diatoms in the Ems estuary has been described previously (de Jonge 1980). This very simple technique for mixed field populations consisting exclusively of motile benthic diatoms is based on a modification of the lens-tissue technique published by Eaton \& Moss (1966). The results revealed that over the course of the whole study $\mathrm{C} / \mathrm{chl}$ a ratios in benthic diatoms varied between ca 10 and 150 . Statistical analyses showed that the ratios did not differ significantly between stations when the samples were taken on the same date. Seasonal differences were very significant. These $\mathrm{C} / \mathrm{chl}$ a ratios can be applied to determine the biomass of the microphytobenthos expressed as carbon in the Ems estuary, because the microphytobenthos in this estuary consists mainly of motile benthic diatoms (de Jonge 1985 . Admiraal et al. 1988).

This paper reports fluctuations of chl a at 6 stations in the Ems estuary, and of biomass calculated by conversion of chl a to carbon using $\mathrm{C} / \mathrm{chl}$ a ratios (de Jonge 1980) obtained for the dates the stations were sampled. Data series are presented to show the strong difference in biomass of microphytobenthos between the top $0.5 \mathrm{~cm}$ and lower segments of the $15 \mathrm{~cm}$ deep sediment column. The implications of the results for ecological studies are discussed.

\section{MATERIALS AND METHODS}

Study area. The Ems estuary (Fig 1) is a coastal plain estuary which crosses the Wadden Sea at the border between The Netherlands and Germany. It is separated from the North Sea by barrier islands, from the mainland by dikes and from adjacent tidal basins by high elevated tidal flats (tidal watersheds). It is ca $75 \mathrm{~km}$ long and encompasses ca $500 \mathrm{~km}^{2}$. Approximately $40 \%$ of the lower reaches and as much as $80 \%$ of the Dollard (upper reaches; Fig. 1) consist of intertidal flats. For hydrographical information see de Jonge $(1988,1992$ a). Investigations were carried out 
in 6 areas distributed over the entire estuary (Fig. 1). In each of these areas transects were chosen. In the present paper we only report on the main stations $(50 \times$ $50 \mathrm{~m}$ ), identified by 2 -digit numbers (10 to 60 ). Stations were located approximately halfway between the highest and lowest level of the sampled tidal flat. The elevation of the stations relative to both Dutch Ordnance Level (DOL) and the tide was different (see Fig. 7).

The sediments of the stations can be characterized as follows. Sandy sediments with a clay content of 1.5 to $2 \%(\mathrm{w} / \mathrm{w})$ were found at $\operatorname{Stn} 10$. Muddy sand with a clay content of 10 to $15 \%$ was found at $S \operatorname{tn} 20$. The sediments of Stn 30 were characterized as sandy mud with a clay content of 10 to $20 \%$. In the middle reaches of the estuary where Stn 40 was situated the clay content was only 2 to $5 \%$, indicating sandy sediment. The sediment of Stn 50 was composed of muddy sand (clay content of 5 to $10 \%$ ), whereas the sediment of Stn 60 was muddy, with a clay content of 30 to $35 \%$.

Sampling. Two independent series of 20 cores (inner diameter of $2.4 \mathrm{~cm}$ each) were taken from the stations for chl a determinations. The replicate samples were taken at regular distances from each other. Cores remained vertical during transport. In vertical position, the sediment column was cut into slices of different thickness. Because of the relatively large diameter and the vertical position, contamination of pigments between slices was assumed to be low.

The uppermost sediment layer had a thickness of $0.5 \mathrm{~cm}$ because the $\mathrm{chl}$ a concentrations determined in that layer were also used for primary production measurements (Colijn \& de Jonge 1984). Each sample of the upper $0.5 \mathrm{~cm}$ layer from the first series of 20 cores was stored separately at $-20^{\circ} \mathrm{C}$ until chl a determination. This procedure was followed to obtain both the means and the standard deviations. The 20 cores of the second series were also sliced. Samples from the second series taken from the sediment layers at 0 to 0.5 , 0.5 to $2.0,2.0$ to $5.0,5.0$ to 10.0 and 10.0 to $15.0 \mathrm{~cm}$ depth were pooled per depth category, mixed thoroughly and subsampled. Three subsamples were taken from each depth category and stored at $-20^{\circ} \mathrm{C}$ until determination of chl $a$. In doing this, only the mean values for chl a were obtained. Because of restricted manpower it was not possible to determine the chl a concentrations in all samples at all depths. [For mixing and subsampling procedures, see de Jonge (1979).]

Stns 10 to 30 were sampled monthly in 1976 and 1978 and fortnightly in 1977 . Stns 40 to 60 were sampled approximately every $2 \mathrm{mo}$, because they were situated far from the mainland and could not be reached without a vessel. In 1978, Stns 40 to 60 were hardly sampled because no ship was available.
Laboratory analyses and calculations. Chl a was determined spectrophotometrically after the samples had been lyophilized. Correction for degradation products was carried out using a modification (Moed \& Hallegraeff 1978) of Lorenzen's (1967) method. This modification is the addition of a well-defined amount of acid, resulting in a better controlled degradation of chl a to phaeophytin than in the original method.

After correction (see 'Results') chl a concentrations from the $2 \mathrm{~cm}$ surface layer were converted to organic carbon using $\mathrm{C} / \mathrm{chl}$ a ratios of vital, motile, benthic diatom populations and, when present, other benthic algae such as the cyanophycean Merismopedia glauca at Stn 10 (de Jonge 1980). Chl a from cyanobacteria was quantitatively determined by applying the LudoxTM separation technique (de Jonge 1979).

\section{RESULTS}

A subjective assessment of the graphs of the mean chl a values (series of non-pooled samples) for the upper $0.5 \mathrm{~cm}$ sediment layer (Fig. 2) suggests dissimilarity in chl $a$ among the 6 stations. Moreover, there are inter-annual variations which differ with station. In 1976 Stns 20 to 50 showed chl a maxima in spring, followed by a sudden or gradual decrease. Stn 10 did not show a clear diatom bloom in 1976, but Stn 60 showed a summer maximum, which was also observed in 1977 for all stations (except Stn 30). In 1978 diatoms at Stns 10 to 30 again bloomed in spring. Generally, most of the stations were characterized by relatively high chl a concentrations in summer; only at Stn 30 did chl a values peak mainly during spring.

The mean chl a concentrations per sampling date were averaged to calculate the annual means (Table 1). A point of interest is the higher chl a concentrations in the Dollard (Table $1_{i}$ Stn 60) as compared with the rest of the estuary. The lowest chl a concentrations were measured at Stn 20.

In Fig. 2 only the mean values of the top $0.5 \mathrm{~cm}$ sediment layer were considered for the different sampling dates and years. However, standard deviations were also calculated for all these values. As an example, the mean chl a concentrations and standard deviations of all stations sampled in 1977 are given in Fig. 3. The year 1977 was sampled most frequently. The graphs show that the standard deviations increase with increasing chl a concentrations; the relatively large coefficients of variation are caused by the irregular or patchy distribution of chl a (cf. van den Hoek et al. 1979).

The chl a concentrations for various depths (obtained from the pooled series of 20 cores) are given in Fig. 4. To ensure a valid comparison all concentrations are 

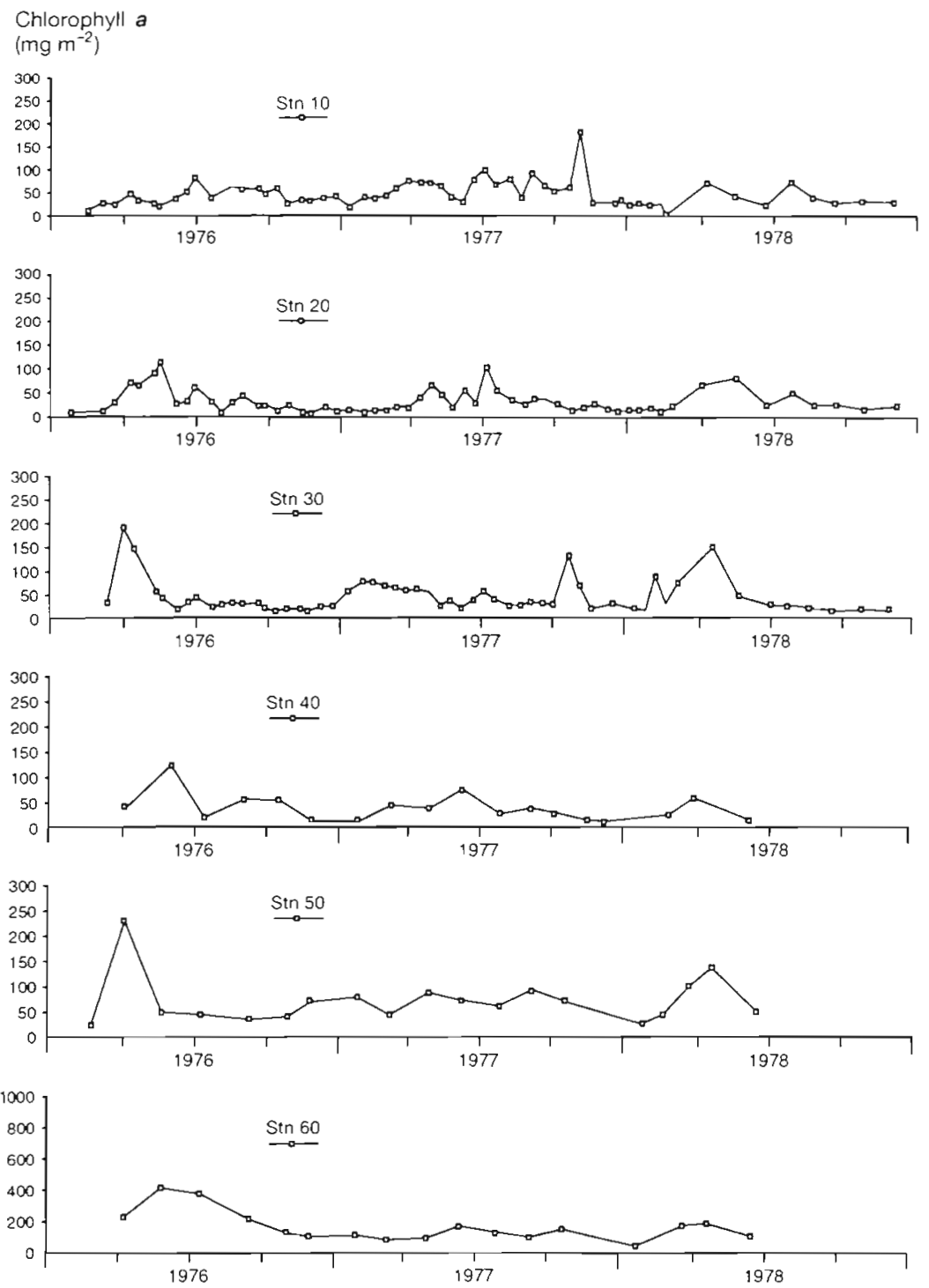

Fig. 2. Mean chl a concentrations per sampling date in the upper $0.5 \mathrm{~cm}$ sediment layer of the stations. All data are expressed as concentrations per $0.5 \mathrm{~cm}$ layer of sediment

expressed per $0.5 \mathrm{~cm}$ of sediment. The graphs show that in general the chl a values were greatest in the upper $0.5 \mathrm{~cm}$ of the sediment. However, there are some exceptions. On some occasions during early spring and in

Table 1. Annual mean $\mathrm{chl}$ a values $\left(\mathrm{mg} \mathrm{m}^{-2}\right.$ ) for the 0 to $0.5 \mathrm{~cm}$ surface layer of the 6 stations

\begin{tabular}{|ccccccc|}
\hline Year & \multicolumn{7}{c|}{ Station } \\
& 10 & 20 & 30 & 40 & 50 & 60 \\
\hline 1976 & 41.4 & 35.1 & 44.1 & 52.8 & 70.7 & 247.0 \\
1977 & 60.2 & 33.1 & 50.2 & 33.2 & 73.5 & 123.8 \\
1978 & 32.5 & 28.6 & 41.9 & 34.4 & 71.9 & 127.8 \\
& & & & & & \\
\hline
\end{tabular}

autumn, and at all stations except 60 (where only limited data are available), the chl a concentrations in the 0.5 to $2.0 \mathrm{~cm}$ sediment layer were higher than those of the top $0.5 \mathrm{~cm}$. Furthermore, the chl a fluctuations in the top $0.5 \mathrm{~cm}$ of the sediment also occurred in the 0.5 to $2.0 \mathrm{~cm}$ layer, and sometimes even in the 2.0 to $5.0 \mathrm{~cm}$ layer. However, the deeper the layers were in the sediment, the weaker the fluctuations (coefficient of variation) in chl a concentration (Fig. 4). For Stns 10 and 50, which have rather sandy sediments, the chl a concentration of the 5.0 to $10.0 \mathrm{~cm}$ layer differed from that of the 10.0 to $15.0 \mathrm{~cm}$ layer. This was certainly not the case for Stns 20 and 30 , which had muddy sand to sandy mud sediments. Stn 60 had very stiff, clay-rich anoxic sediments that were difficult to sample at depths below $2 \mathrm{~cm}$, and presumably also falls into the latter group. The values in Fig. 4 indicate the depths to which benthic diatoms may be found (see also Fig. 5, and Joint 1981, Baillie 1987 and Admiraal et al. 1988).

Without chromatographical separation, spectrophotometric determinations of chl a also include derivatives such as chlorophyllide a (Daemen 1985). For that reason a correction was required before these pigment concentrations could be converted to organic carbon by the $\mathrm{C} / \mathrm{chl}$ a ratios (de Jonge 1980) for the same dates.

The measured chl a values per station per depth were averaged for those sampling dates when sediment layers deeper than $2 \mathrm{~cm}$ were also sampled (cf. Fig. 4). These mean values were plotted as a percentage of the value for the uppermost $0.5 \mathrm{~cm}$, which was considered to be unity $(100 \%)$. The resulting mean relative depth distributions of the total chl a concentrations are given in Fig. 5A. Before these distributions were used for further calculations, Spearman's rank correlation coefficients were calculated to test the hypothesis that chl a concentrations at the different levels fluctuated independently. The test results in Table 2 show that this hypothesis usually held for depths greater than $2 \mathrm{~cm}$. But it also held for the 2 upper layers of the sandy Stns 40 and 50 . Thus, based on a statistical test, there is evidence that the chl a fluctuations in the 2 upper sediment layers of 4 out of 6 stations were related to each other. 
However, the available data indicate that the vertical distribution of chl a of all the stations cannot simply be described as a function of the surface value. Except for Stn 60, for depths below $2 \mathrm{~cm}$ the $\mathrm{chl}$ a concentrations steadily decreased independently of the surface value (see relative distribution profile in Fig. 5A). This is an indication that the sediments deeper than $2 \mathrm{~cm}$ contained chl a and/or derivatives that also absorb at the chl a maximum, but had pigment levels showing little or no relation with the transient surface concentrations that were mainly derived from vital populations. Thus, the relative vertical distribution of chl a and derivatives could be used to reconstruct roughly the mean original vertical distribution of chl a. To do so, the value for the 2.0 to $5.0 \mathrm{~cm}$ layer (the depth from which the steady decrease in chl a was ascertained; Fig. 5A) was connected with the $0 \%$ value at the surface (Fig. 5B), and the value at $1.25 \mathrm{~cm}$ depth was subtracted from the measured value in the 0.5 to $2.0 \mathrm{~cm}$ layer. The resulting plots (Fig. 5C) represent the mean relative vertical distribution of chl a derived solely from vital algae. This graph is assumed to reach a level of $0 \%$ chl a at a depth of 2.0 to $5.0 \mathrm{~cm}$, which of

Table 2. Results of Spearman's rank correlation tests applied to chl a concentrations determined for different sediment depths at the stations. ns: not significant

\begin{tabular}{|c|c|c|c|c|c|}
\hline \multirow[t]{2}{*}{ Station } & \multicolumn{2}{|c|}{ Depth of layer $(\mathrm{cm})$} & \multirow[t]{2}{*}{$\mathrm{n}$} & \multirow[t]{2}{*}{ I } & \multirow[t]{2}{*}{$p$} \\
\hline & $x$ & $y$ & & & \\
\hline \multirow[t]{2}{*}{10} & $0-0.5$ & $0.5-2.0$ & 24 & 0.53 & 0.011 \\
\hline & $0-0.5$ & $2.0-5.0$ & 24 & 0.24 & $0.258 \mathrm{~ns}$ \\
\hline \multirow[t]{2}{*}{20} & $0-0.5$ & $0.5-2.0$ & 23 & 0.82 & 0.0001 \\
\hline & $0-0.5$ & $2.0-5.0$ & 23 & 0.39 & $0.070 \mathrm{~ns}$ \\
\hline \multirow[t]{3}{*}{30} & $0-0.5$ & $0.5-2.0$ & 20 & 0.67 & 0.004 \\
\hline & $0-0.5$ & $2.0-5.0$ & 20 & 0.65 & 0.004 \\
\hline & $0-0.5$ & $5.0-10.0$ & 20 & 0.39 & $0.087 \mathrm{~ns}$ \\
\hline \multirow[t]{2}{*}{40} & $0-0.5$ & $0.5-2.0$ & 12 & 0.34 & $0.256 \mathrm{~ns}$ \\
\hline & $0-0.5$ & $2.0-5.0$ & 2 & - & - \\
\hline \multirow[t]{2}{*}{50} & $0-0.5$ & $0.5-2.0$ & 15 & 0.41 & $0.121 \mathrm{~ns}$ \\
\hline & $0-0.5$ & $2.0-5.0$ & 5 & 0.40 & $0.424 \mathrm{~ns}$ \\
\hline \multirow[t]{2}{*}{60} & $0-0.5$ & $0.5-2.0$ & 12 & 0.75 & 0.012 \\
\hline & $0-0.5$ & $2.0-5.0$ & 3 & -1.00 & $<0.0001$ \\
\hline
\end{tabular}

course is an approximation and not necessarily completely true (cf. Admiraal et al. 1988). Nevertheless, this general approach was used to correct the available pigment data for non-chl a caused by the presence of coloured compounds, derivatives as chlorophyllide $a$, etc. Without correction, conversion of chl a to organic carbon is senseless because the bulk of the algal chl a including derivatives ( 65 to $93 \%$; cf. Table 3 ) is present far below the euphotic layer in the sediment, which is at most $3 \mathrm{~mm}$ thick (Colijn 1982). This means that only a very small percentage of the algal chl a from vital cells is available to sustain this total mass or even to cause it to grow. From the graphs in Fig. 5A \& C a factor was calculated to convert the chl a values from the pooled 0.5 to $2.0 \mathrm{~cm}$ layers, where a mixture of chl a from vital algal cells as well as other absorbing compounds was assumed to be present, into chl a from vital microphytobenthos (cf. Table 3).

Data published by de Jonge (1980) were used to calculate running mean $\mathrm{C} / \mathrm{chl}$ a ratios over a period of $5 \mathrm{wk}$, to prevent extreme fluctuations in carbon biomass after the chl a values had been multiplied by the $\mathrm{C} / \mathrm{chl}$ a ratios. As expected, the chl a values in the 0 to $2.0 \mathrm{~cm}$ layer (Fig. 6, open triangles) were higher during summer and lower during winter, but with the exception of $\operatorname{Stn} 20$ a 

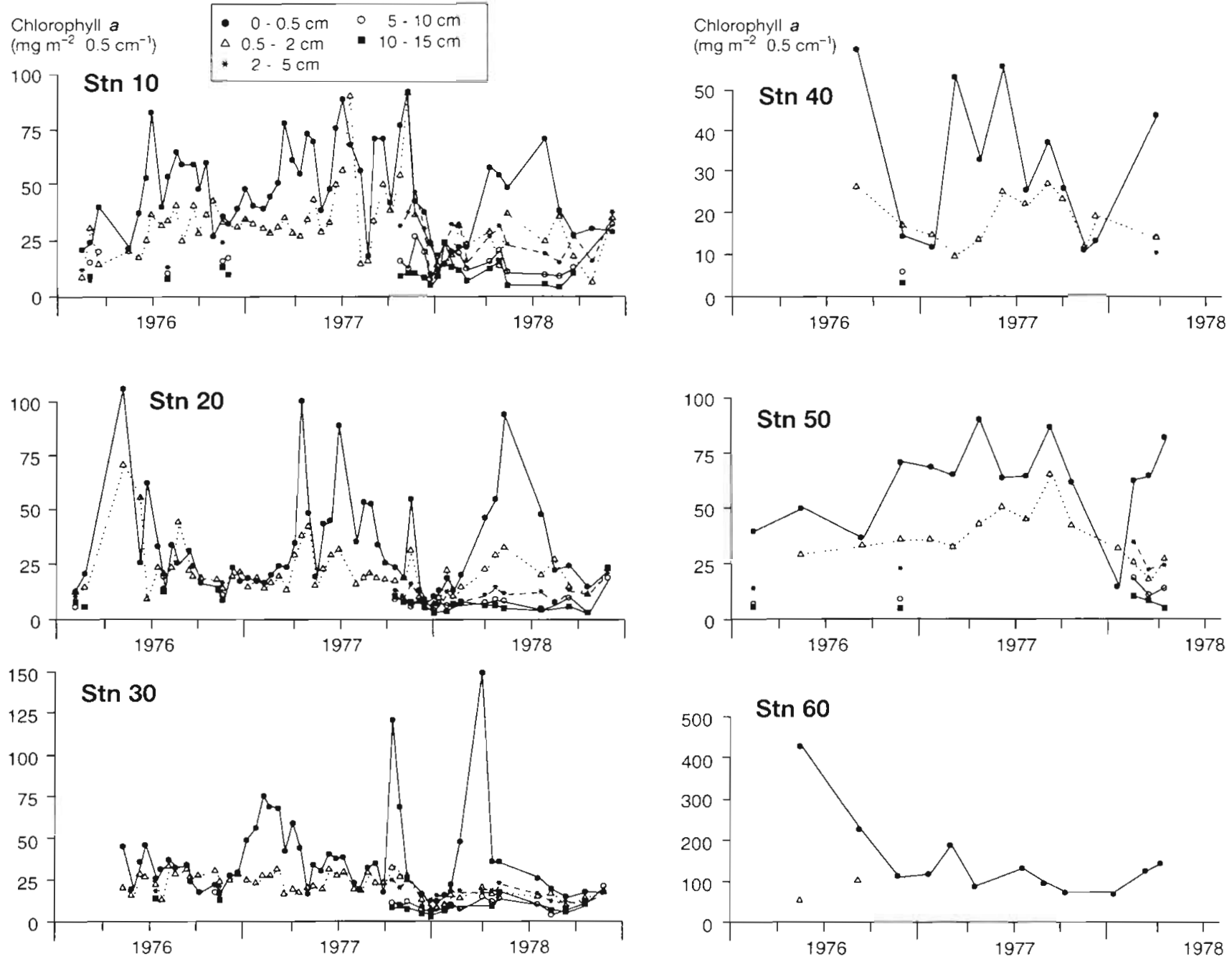

Fig. 4. Mean chl a concentrations in various depth layers for the 6 stations. All data are expressed as concentrations per $0.5 \mathrm{~cm}$ sediment layer
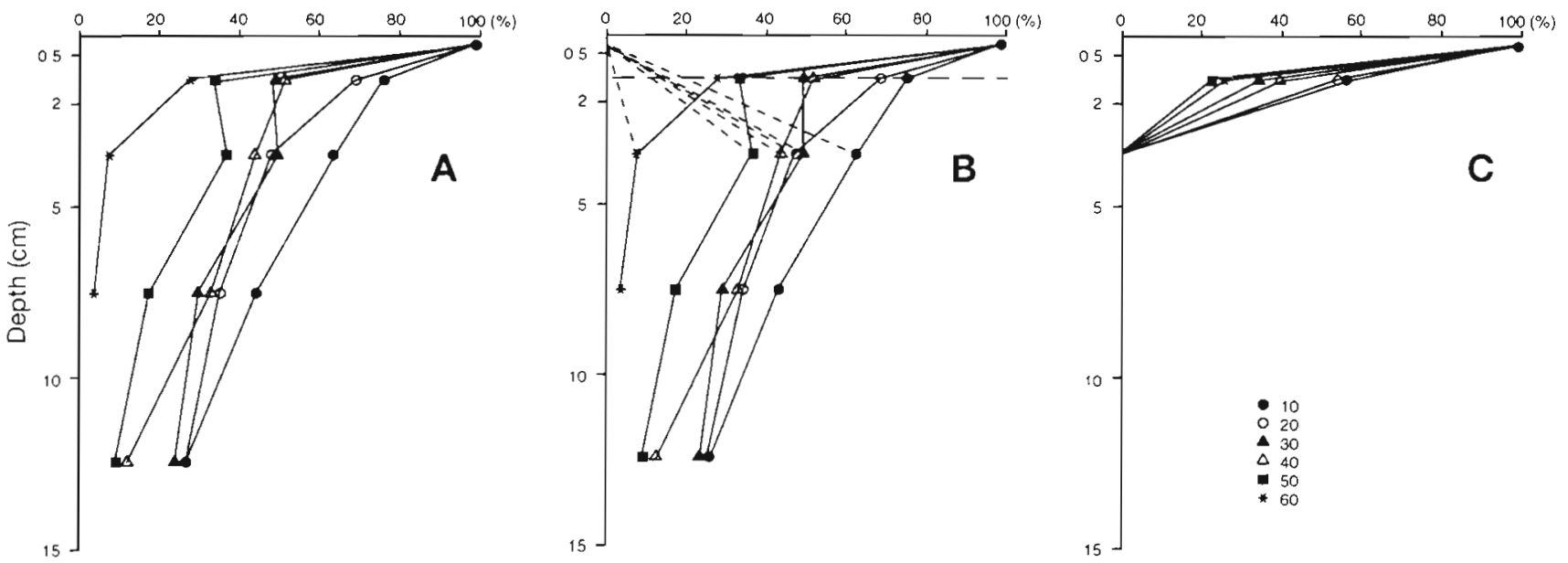

Fig. 5. Relative depth distributions of chl a for the 6 stations. (A) Distribution of mean total chl $a$; (B) calculation of difference between chl a from vital microphytobenthos and other sources ('detrital'; see text); (C) distribution of chl a from vital microphyto- 
Table 3. Absolute (Abs.) and relative (\%) chl a values in layers sampled between the surface and $15 \mathrm{~cm}$ depth for all stations. Also shown is the corrected relative vertical distribution of chl $a$, from which a correction factor for converting total chl $a$ in the 0.5 to $2.0 \mathrm{~cm}$ layer to $\mathrm{chl}$ a from vital microphytobenthos (cf. Fig. 5) was calculated. Absolute concentrations are given as mg $\mathrm{chl}^{2} \mathrm{~m} \mathrm{~m}^{-2}$ $0.5 \mathrm{~cm}^{-1}$ See Table 2 for number of observations

\begin{tabular}{|c|c|c|c|c|c|c|c|c|c|c|c|c|}
\hline \multirow{3}{*}{$\begin{array}{c}\text { Layer } \\
(\mathrm{cm})\end{array}$} & \multicolumn{12}{|c|}{ Station } \\
\hline & \multicolumn{2}{|c|}{10} & \multicolumn{2}{|c|}{20} & \multicolumn{2}{|c|}{30} & \multicolumn{2}{|c|}{40} & \multicolumn{2}{|c|}{50} & \multicolumn{2}{|c|}{60} \\
\hline & Abs. & $\%$ & Abs. & $\%$ & Abs. & $\%$ & Abs. & $\%$ & Abs. & $\%$ & Abs. & $\%$ \\
\hline $0-0.5$ & 38.3 & 100 & 25.5 & 100 & 35.4 & 100 & 28.7 & 100 & 62.8 & 100 & 122.4 & 100 \\
\hline $0.5-2.0$ & 29.0 & 76 & 17.6 & 69 & 17.3 & 49 & 15.1 & 52 & 21.7 & 34 & 34.2 & 28 \\
\hline $2.0-5.0$ & 24.1 & 63 & 12.3 & 48 & 17.4 & 49 & 12.5 & 44 & 23.2 & 37 & 9.8 & 8 \\
\hline $5.0-10.0$ & 16.7 & 44 & 9.0 & 35 & 10.8 & 30 & 9.7 & 34 & 11.6 & 18 & 5.2 & 4 \\
\hline $10.0-15.0$ & 10.3 & 27 & 6.8 & 27 & 8.6 & 24 & 3.6 & 13 & 6.3 & 10 & - & - \\
\hline \multicolumn{13}{|c|}{ Relative distribution of $\mathrm{chl}$ a from vital microphytobenthos $(\%)$ : } \\
\hline $0-0.5$ & \multicolumn{2}{|c|}{100} & \multicolumn{2}{|c|}{100} & \multicolumn{2}{|c|}{100} & \multicolumn{2}{|c|}{100} & \multicolumn{2}{|c|}{100} & \multicolumn{2}{|c|}{100} \\
\hline $0.5-2.0$ & \multicolumn{2}{|c|}{56.5} & \multicolumn{2}{|c|}{54.5} & \multicolumn{2}{|c|}{34} & \multicolumn{2}{|c|}{39} & \multicolumn{2}{|c|}{23} & \multicolumn{2}{|c|}{25.5} \\
\hline $2.0-5.0$ & \multicolumn{2}{|c|}{0} & \multicolumn{2}{|c|}{0} & \multicolumn{2}{|c|}{0} & \multicolumn{2}{|c|}{0} & \multicolumn{2}{|c|}{0} & \multicolumn{2}{|c|}{0} \\
\hline $5.0-10.0$ & \multicolumn{2}{|c|}{0} & \multicolumn{2}{|c|}{0} & \multicolumn{2}{|c|}{0} & \multicolumn{2}{|c|}{0} & \multicolumn{2}{|c|}{0} & \multicolumn{2}{|c|}{0} \\
\hline $10.0-15.0$ & \multicolumn{2}{|c|}{0} & \multicolumn{2}{|c|}{0} & & 0 & & 0 & & 0 & & 0 \\
\hline Chl a corr & i for 0 & -2.0 & lepth & & & & & & & & & \\
\hline & & & & & 0.6 & & 0 . & & & & 0. & \\
\hline
\end{tabular}

pronounced seasonal pattern was absent. This was true not only for the upper $2 \mathrm{~cm}$ but also for the upper $0.5 \mathrm{~cm}$ layer (cf. Fig. 2).

The organic carbon values resulting from the multiplication of chl a concentrations and the $\mathrm{C} / \mathrm{chl}$ a ratios for each occasion are also given in Fig. 6. Despite the large number of fluctuations in carbon values, the graphs generally show seasonal fluctuations, with relatively low organic carbon values in winter and relatively high values in other periods of the year. Except for $\operatorname{Stn} 60$, the maximum carbon values are approximately the same per station over all years; this is certainly not true for chl a.

For comparison, Table 4 presents the mean annual values of both chl a and organic carbon for the different stations and sediment layers. The smallest mean total biomass (Table 4), with an overall value between 3.2 and $3.9 \mathrm{~g} \mathrm{C} \mathrm{m}^{-2}$, was found in the middle reaches of the estuary (Stns 20 and 40 ) and part of the Dollard (Stn 30). A value of $5.5 \mathrm{~g} \mathrm{C} \mathrm{m}^{-2}$ was found at Stn $10 \mathrm{in}$ the lower reaches, while the highest biomass (6.6 and $11 \mathrm{~g} \mathrm{C} \mathrm{m}^{-2}$ ) occurred at Stns 50 and 60 in the Dollard. When comparing stations based on the chl a values, the same picture emerges because the $\mathrm{C} / \mathrm{chl}$ a ratios did not differ over stations but only over seasons.

The vertical distribution of algal biomass (Table 4) shows that, either in terms of chl a or organic carbon, the relative contribution in the 0 to $0.5 \mathrm{~cm}$ sediment layer to the total biomass of the upper $2 \mathrm{~cm}$ increased from 0.40 at the most exposed station in the lower reaches to 0.61 at Stn 60 in the most upstream area.
The mean annual $\mathrm{C} / \mathrm{chl}$ a ratios for the 3 years of investigation were 40,41 and 61 respectively (de Jonge 1980) and are indicative of the year-to-year fluctuations that can occur.

\section{DISCUSSION}

\section{Applied methods and procedures}

Using the conventional spectrophotometric method applied in this study, it is not possible to make a clear distinction between the chl a (biomass) of living microphytobenthos cells and derivatives. It is known (Daemen 1985) that for Dutch estuarine sediments the method of Lorenzen (1967) overestimates chl a content by ca $30 \%$ compared with results of HPLC. However, in the late 1970s the HPLC technique (Riaux-Gobin et al. 1987) was not available to separate chl a from other pigments in estuarine areas. This was the main reason for application of a conversion procedure to obtain the best possible estimate of the chl $a$ in vital microphytobenthos. However, the same problem also holds for other techniques. Every biomass value produced is an estimate because none of the available parameters that can be measured (cell counts, organic carbon, chl a, intact diatom frustules, etc.) unambiguously reflects algal biomass expressed in organic carbon.

A different procedure to correct for chl a derivatives could have been used, starting from the assumption that the smallest chl a concentration below the top layer con- 
Biomass $\left(\mathrm{gC} \mathrm{m}^{-2}\right)$
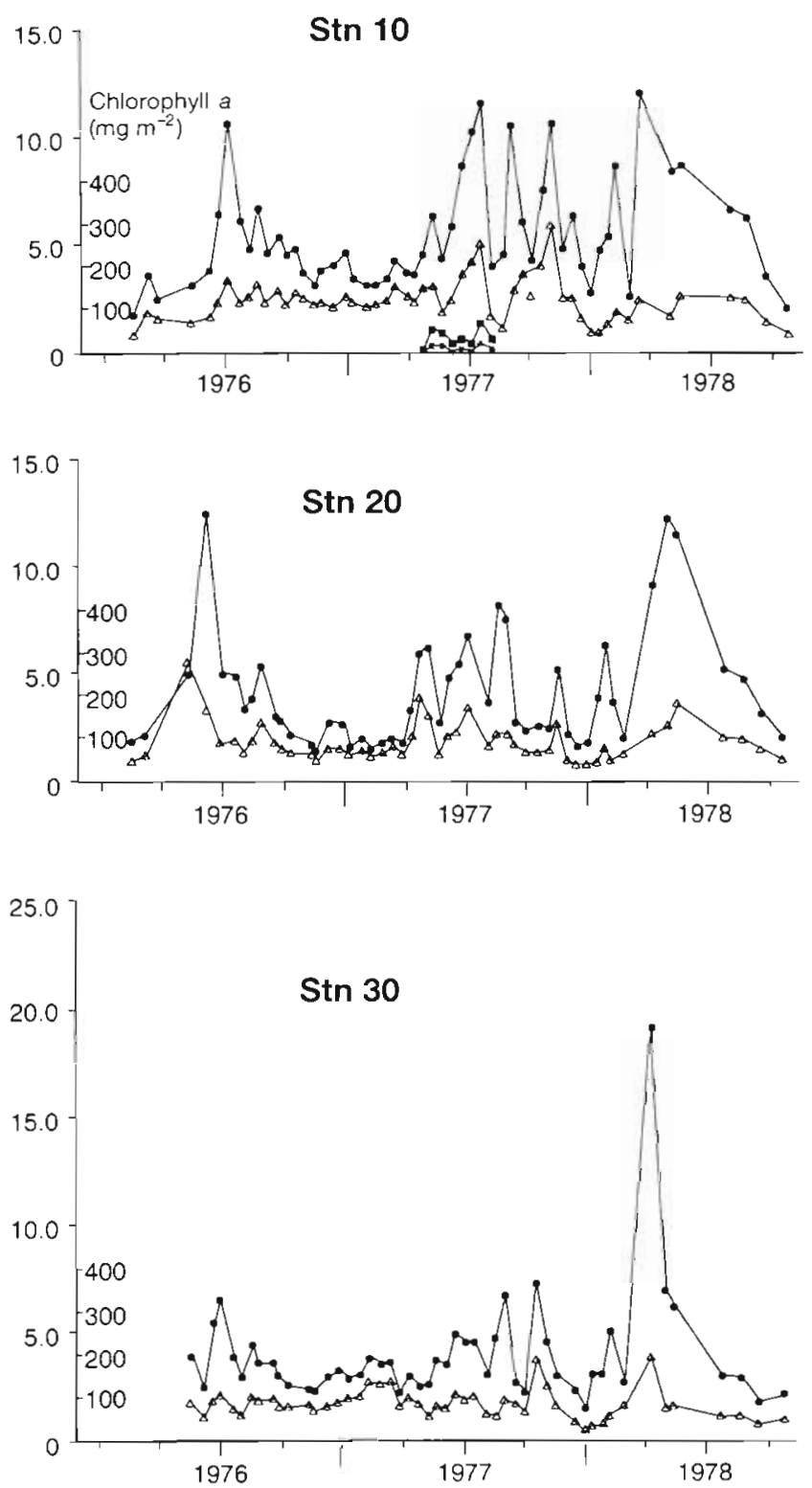

Biomass $\left(\mathrm{gC} \mathrm{m}^{-2}\right)$

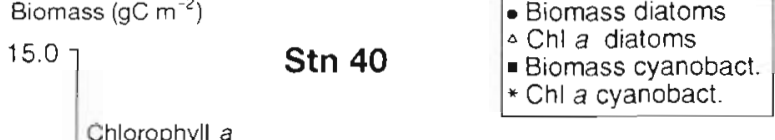

10.0

Chlorophyll a

10.0 -( $\mathrm{mg} \mathrm{m}^{-2}$ )
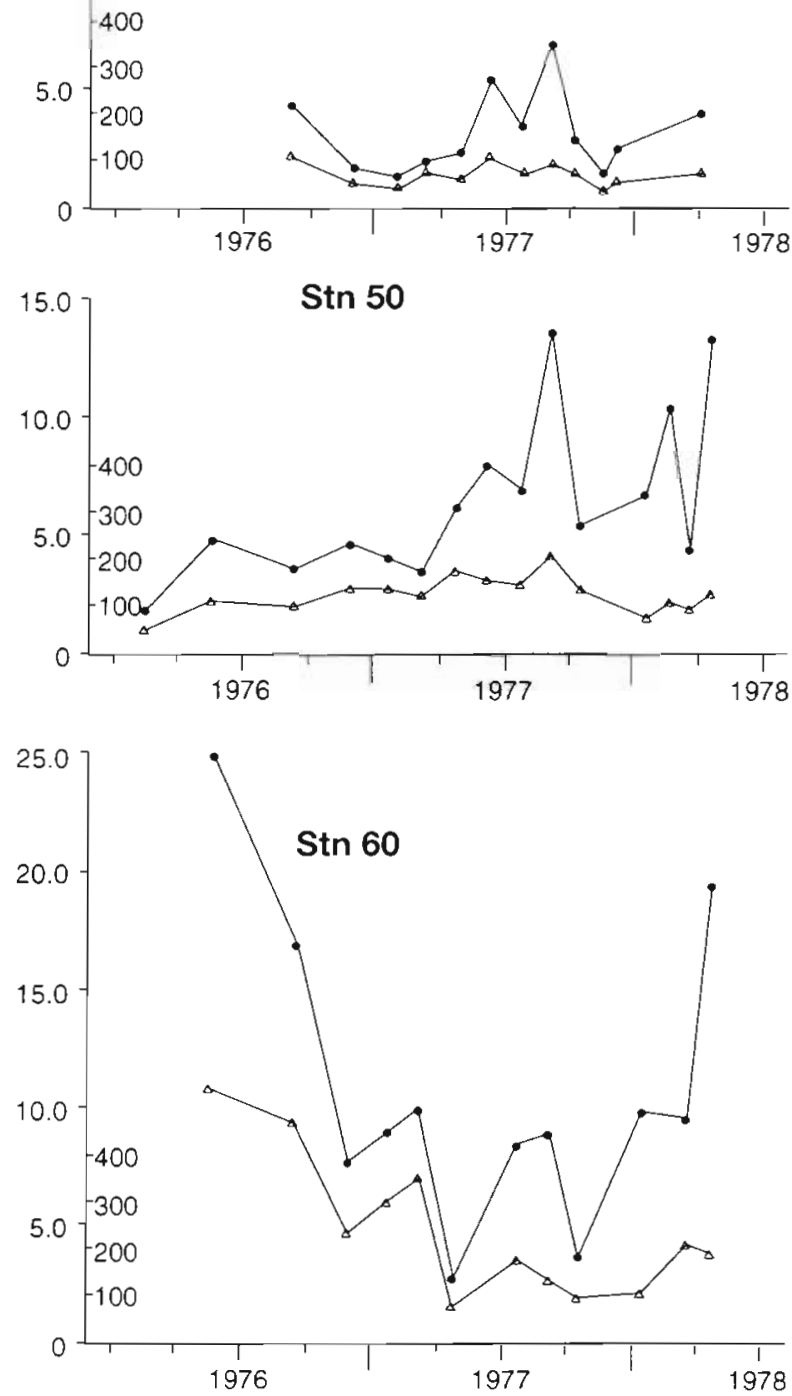

Fig. 6. Microphytobenthic biomass in the uppermost $2 \mathrm{~cm}$, expressed as chl a and organic carbon, per sampling date for the 6 stations. Carbon values were obtained by multiplying the $\mathrm{C} / \mathrm{chl}$ a ratios (de Jonge 1980 ) by the sum of the chl $a$ values for the $0.5 \mathrm{~cm}$ sediment layer (Fig. 2) and the corrected values for the 0.5 to $2.0 \mathrm{~cm}$ laver (cf. Fig 5)

sists exclusively of 'detrital' chl a derived from either dead algae or pigment derivatives. This implies that the chl a concentration in the uppermost $2 \mathrm{~cm}$ should be reduced by this background value, because it can be hypothesized that the 'detrital' chl a at depth is equal to that at the surface as a result of sediment turbation. However, in applying this assumption many negative biomass values were obtained for the top $0.5 \mathrm{~cm}$ layer of sediment. This suggests that the assumption that the 'detrital' chl $a$ is approximately zero at the surface and increases with depth is more feasible. The difference in mean annual biomass for Stns 10 and 30 in 1977 was calculated using both assumptions. The total biomass over the uppermost $2 \mathrm{~cm}$ at Stns 10 and 30 was 24 and $29 \%$ lower, respectively, when the initial assumption was used. Despite this difference, the agreement is surprisingly good, but, as already mentioned, the disadvantage of the second procedure is that many negative biomass values occur, which restricts the usefulness of this alternative correction method. 
Table 4. Mean annual values of chl $a$ and organic carbon for the stations and the sediment layers

\begin{tabular}{|c|c|c|c|c|c|c|c|c|c|c|}
\hline \multirow[t]{2}{*}{ Station } & \multirow[t]{2}{*}{ Yеar } & \multicolumn{3}{|c|}{ Chl $a\left(\mathrm{mg} \mathrm{m}^{-2}\right)$} & \multirow[t]{2}{*}{$\mathrm{n}$} & \multicolumn{3}{|c|}{ Biomass $\left(\mathrm{g} \mathrm{C} \mathrm{m}^{-2}\right)$} & \multirow[t]{2}{*}{$\mathrm{n}$} & \multirow{2}{*}{$\begin{array}{c}\text { Biomass ratio } \\
(0-0.5 \mathrm{~cm} / 0-2.0 \mathrm{~cm})\end{array}$} \\
\hline & & $0-0.5 \mathrm{~cm}$ & $0.5-2.0 \mathrm{~cm}$ & $0-2.0 \mathrm{~cm}$ & & $0-0.5 \mathrm{~cm}$ & $0.5-2.0 \mathrm{~cm}$ & $0-2.0 \mathrm{~cm}$ & & \\
\hline \multirow[t]{4}{*}{10} & 1976 & 44.2 & 66.2 & 110.4 & 19 & 1.93 & 2.76 & 4.69 & 19 & \\
\hline & 1977 & 56.4 & 87.1 & 143.5 & 24 & 2,30 & 3.68 & 5.98 & 24 & \\
\hline & 1978 & 34.1 & 51.0 & 85.1 & 13 & 2.49 & 3.50 & 5.99 & 12 & \\
\hline & Mean & 47.1 & 71.6 & 118.7 & 56 & 2.21 & 3.32 & 5.54 & 15 & 0.40 \\
\hline \multirow[t]{4}{*}{20} & 1976 & 29.3 & 59.6 & 88.8 & 16 & 1.28 & 2.42 & 3.70 & 16 & \\
\hline & 1977 & 32.5 & 47.8 & 80.4 & 28 & 1.42 & 1.99 & 3.41 & 28 & \\
\hline & 1978 & 26.4 & 40.6 & 67.0 & 17 & 1.99 & 3.00 & 4.99 & 16 & \\
\hline & Mean & 30.0 & 48.9 & 78.9 & 61 & 1.51 & 2.34 & 3.84 & 60 & 0.40 \\
\hline \multirow[t]{4}{*}{30} & 1976 & 28.7 & 51.2 & 79.9 & 15 & 1.31 & 2.20 & 3.51 & 15 & \\
\hline & 1977 & 43.6 & 48.0 & 91.6 & 23 & 1.66 & 1.98 & 3.64 & 23 & \\
\hline & 1978 & 32.0 & 28.4 & 60.4 & 13 & 2.67 & 2.07 & 4.74 & 12 & \\
\hline & Mean & 36.3 & 43.9 & 80.2 & 51 & 1.80 & 2.07 & 3.87 & 50 & 0.46 \\
\hline \multirow[t]{4}{*}{40} & 1976 & 73.0 & 47.8 & 120.8 & 2 & 1.34 & 1.72 & 3.06 & 2 & \\
\hline & 1977 & 29.1 & 40.8 & 69.9 & 9 & 1.29 & 1.90 & 3.19 & 9 & \\
\hline & 1978 & 43.1 & 30.8 & 73.9 & 1 & 2.40 & 1.71 & 4.11 & 1 & \\
\hline & Mean & 37.6 & 41.1 & 78.7 & 12 & 1.39 & 1.85 & 3.24 & 12 & 0.43 \\
\hline \multirow[t]{4}{*}{50} & 1976 & 48.2 & 50.6 & 98.8 & 4 & 1.83 & 1.92 & 3.75 & 4 & \\
\hline & 1977 & 70.1 & 89.5 & 159.6 & 7 & 2.98 & 3.98 & 6.96 & 7 & \\
\hline & 1978 & 55.1 & 50.8 & 105.9 & 4 & 4.52 & 4.35 & 8.87 & 4 & \\
\hline & Mean & 60.2 & 68.8 & 129.0 & 15 & 3.08 & 3.53 & 6.61 & 15 & 0.47 \\
\hline \multirow[t]{4}{*}{60} & 1976 & 247.4 & 172.1 & 419.5 & 3 & 10.16 & 6.51 & 16.67 & 3 & \\
\hline & 1977 & 108.8 & 84.5 & 193.3 & 6 & 4.21 & 2.97 & 7.18 & 6 & \\
\hline & 1978 & 107.3 & 66.7 & 174.0 & 3 & 8.32 & 4.73 & 13.05 & 3 & \\
\hline & Mean & 143.1 & 102.0 & 245.0 & 12 & 6.72 & 4.20 & 11.02 & 12 & 0.61 \\
\hline
\end{tabular}

In food web studies and studies of energy fluxes, it is important to determine the biomass of microphytobenthos as accurately as possible because these algae provide food for grazers. As shown here, part of this food is distributed through the sediment column, whereas another part (de Jonge \& van Beusekom 1992) reaches the water column during high tide, where it is redistributed over the estuary. Seasonal changes in growth conditions and the resuspension of benthic diatoms combine to determine the fluctuations in concentrations of chl $a$ in the sediments (cf. de Jonge 1992b).

To convert chl a into organic carbon accurately, reliable $\mathrm{C} / \mathrm{chl}$ a ratios must be available for the different parts of the ecosystem (water, sediment surface and deeper sediment layers). But, these values are not measurable at present. Only concentrations of chl a at different depths in the sediment were available, together with the $\mathrm{C} / \mathrm{chl}$ a ratios for living motile benthic diatoms collected from the top layer of the sediments at the different stations. Still, it can be assumed that beneath the euphotic zone the general pool of organic carbon is utilised more rapidly than the chl a (Admiraal \& Peletier 1979, Admiraal 1984) and that the carbon extraction from the cells below the upper $2 \mathrm{~cm}$ layer, in which the chl a levels follow each other closely, is more rapid than that of the upper $2 \mathrm{~cm}$. This will result in declining $\mathrm{C} / \mathrm{chl}$ a ratios with increasing sediment depth. This assumption led to the development of the applied conversion procedure (cf. Fig. 5) to estimate the total biomass of the microphytobenthos.

\section{Vertical distribution of biomass in sediments}

The observations of chl a in significant concentrations at depths of $15 \mathrm{~cm}$, far below the $3 \mathrm{~mm}$ (at maximum) thick euphotic zone, are consistent with data published by Moul \& Mason (1957), Hopkins (1963), Taylor \& Gebelein (1966), Pamatmat (1968), Steele \& Baird (1968), Fenchel \& Staarup (1971), Cadée \& Hegeman (1974) and Colijn (1982).

It is known that buried diatoms can survive by employing adaptation mechanisms such as the uptake of dissolved organic compounds (Admiraal 1984). However, only a few observations indicating the relative depth distribution of vital algae cells in intertidal sediments are available. Joint (1981) published data on the depth distribution of both chl $a$ and fluorescing cells for 
an English estuary and showed that chl a declined over the top $\mathrm{cm}$. Below this depth the concentrations stabilized up to a depth of $9 \mathrm{~cm}$. This is comparable with the values presented here. The decline in cell numbers is also noteworthy. Most of the cells are present in the top $2 \mathrm{~cm}$, and the relative contribution of cells beneath 4 $\mathrm{cm}$ depth is insignificant. Baillie (1987), working on soft sediments, showed that the bulk of microphytobenthic cells was present in the upper 2 to $3 \mathrm{~cm}$. Larger cells were most numerous at a depth of approximately $2 \mathrm{~cm}$. Admiraal et al. (1988) gave some examples of cell depth distributions at 3 different localities in the Ems estuary. The distributions clearly show the restricted depth at which diatoms were found at Stn 60 (see also Fig. 5). Benthic diatoms from Stn 50 had a distribution that reached depths of approximately $10 \mathrm{~cm}$, whereas small (most likely sand-adhered) diatom cells at Stn 10 reached depths of $15 \mathrm{~cm}$. Cell numbers declined over the top 2 to $5 \mathrm{~cm}$ here as well. Note, however, that cell numbers in sandy sediments such as those occurring at Stn 10 may reach considerable levels even at depths of $15 \mathrm{~cm}$. These cells, however, are very small and despite their abundance hardly contribute to the biomass. Although the values published elsewhere do not show how microphytobenthos biomass varies with depth, they do illustrate that microphytobenthos biomass is not important at depths below $5 \mathrm{~cm}$, a boundary also found based on statistical evaluation in the present study.

The distribution of biomass with depth (Fig. 5C) of the benthic diatoms should be assessed under field conditions. Although the present analysis of microphytobenthos depth distribution was not available at the time of the final BOEDE (project: Biological Research Ems-Dollard Estuary) report on modelling the ecosystem of the Ems estuary (Baretta \& Ruardij 1988), the graphs presented in Fig. 5C correspond very well with the graphs of relative biomass in Baretta \& Ruardij (1988, Fig. 7.3). Interestingly, the previously published graphs were not based solely on preliminary analyses of field data but also on practical considerations such as food availability for grazers and theoretical considerations such as production/biomass ratios. When the biomass values calculated in this study for the upper $0.5 \mathrm{~cm}$ and the upper $2.0 \mathrm{~cm}$ layers were compared with model calculations (Baretta \& Ruardij 1988, p. 206), they were found to be of the same order of magnitude. In Baretta \& Ruardij (1988) the total biomass in a sediment column of $30 \mathrm{~cm}$ was calculated to range from 2 to $25 \mathrm{~g} \mathrm{C} \mathrm{m}^{-2}$, whereas the amount in the top $0.5 \mathrm{~cm}$ ranged from 1 to $10 \mathrm{~g} \mathrm{C} \mathrm{m}^{-2}$. Thus, the total biomass in the entire column was, on average, only twice that of the top $0.5 \mathrm{~cm}$ layer, except for Stn 60 where $75 \%$ of the total biomass was present in that layer. Within the top $5 \mathrm{~cm}$ the mean total biomass ranged from $97 \%$ (in the area of $\operatorname{Stn} 60$ ) to $87 \%$ (in the area of Stn 10) of the total.

In this study differences in the relative distribution of microphytobenthos with depth between stations (Admiraal et al. 1988) were disregarded because only a limited data set was available on this vertical distribution (cf. Fig. 4 and Table 3).

\section{Seasonal variation of biomass}

Chl a measurements from the top $0.5 \mathrm{~cm}$ are often used to calculate microphytobenthos biomass in the sediment. But, this may lead to underestimates of the biomass available for grazers, depending on where the grazers are (water column or sediment). In general, for grazers in the water column 2 such underestimates may occur. The first is caused by the seasonal change in $\mathrm{C} / \mathrm{chl} \mathrm{a}_{i}$ resulting in a clear seasonal fluctuation in algal carbon but not in chl a (Fig. 6). This weak seasonal pattern for chl a seems very common at our latitude. Pamatmat (1968), Steele \& Baird (1968), Leach (1970), Cadée \& Hegeman (1974) and Colijn \& de Jonge (1984) also reported that only moderate differences if any occurred in microphytobenthos chl a between winter and summer, suggesting that biomass differences between summer and winter are small. The second important underestimate is caused by using only the top $0.5 \mathrm{~cm}$ of the sediment. In this case only 35 to $60 \%$ of the total biomass is taken into account (cf. Table 4). The use of an 'incorrect' $\mathrm{C} / \mathrm{chl}$ a ratio when considering grazers which are able to exploit the upper 10 to $20 \mathrm{~cm}$ of the sediment (Arenicola marina and Mya arenaria) can increase this deviation by a further $50 \%$ (see above). This highlights the importance, depending on the aim, of using the proper depth distribution of diatom chl a as well as the proper $\mathrm{C} / \mathrm{chl}$ a ratio.

\section{Processes controlling temporal dynamics}

The biomass (organic carbon) graphs presented in Fig. 6 show an irregular seasonal pattern. The causes for temporary reductions in microphytobenthos biomass could be grazing, poor light conditions due to overcast skies in winter, bioturbation, mortality, lunar-induced changes in tidal currents and wave action caused by changing wind speed. There is seasonal fluctuation in the activity of the biotic components (grazers and burrowers) that can cause a biomass reduction in microphytobenthos (cf. Admiral et al. 1983). However, despite calculations presented by Montagna (1984) and Gould \& Gallagher (1990), it is improbable that mainly grazers and burrowers are responsible for the some- 


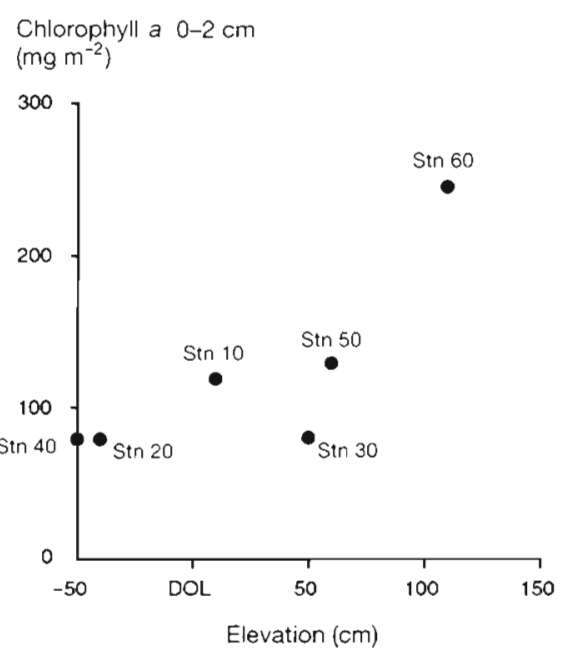

Fig. 7. Plot of 3-year mean values of microphytobenthos chl a concentrations in the top $2 \mathrm{~cm}$ (left half) and the top $0.5 \mathrm{~cm}$ (right half) of the sediment vs sampling station elevation. DOL: Dutch Ordnance Level

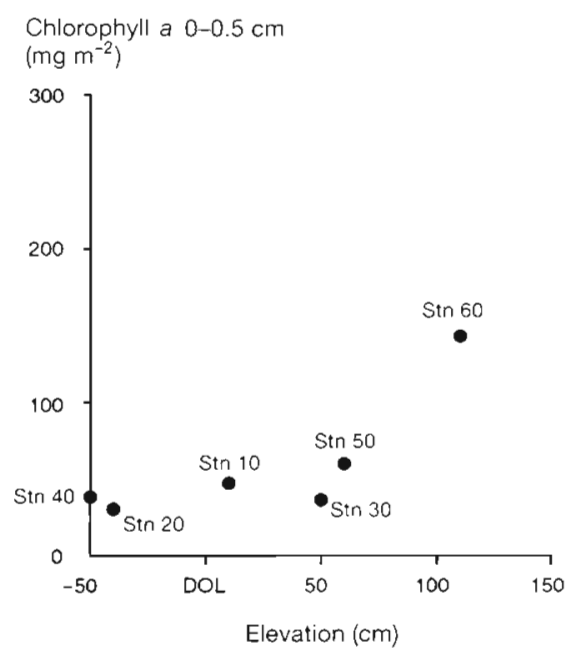

LITERATURE CITED times strong changes in biomass concentrations observed within a period of only $14 \mathrm{~d}$ (cf. Fig. 6: 1977 carbon graphs). This leaves light (clear or dull summers), tidal currents (spring-neap cycle) and wind-induced waves as the factors most likely to have caused the irregularities. Considering the changes in wind speed that occur here, and given the results of a study of resuspension processes in this estuary (de Jonge \& van Beusekom 1992), it seems probable that strong reductions in microphytobenthos biomass in the upper sediment layers coincide with periods of relatively high wind speed (cf. also Colijn \& Dijkema 1981). Tidal currents also contribute to the resuspension of microphytobenthos (de Jonge 1992b), i.e. they bring about transport between tidal flats and channels, but the available results indicate that wind-induced waves are far more important than tidal currents. Thus, wind-induced waves are the main cause of resuspension, whereas light conditions [related to station elevation (Admiraal \& Peletier 1980), solar radiation and water turbidity (Colijn 1983, p. 104)] are responsible for microphytobenthos growth, as reported by Colijn \& de Jonge (1984). The combined effect of these factors leads to a pattern as presented in Fig. 7, where the mean chl a concentration per station over the whole research period is plotted as a function of station elevation. Of course this picture is very similar to the relation between annual primary production of the microphytobenthos reported for the same stations by Colijn \& de Jonge (1984), who found a fair correlation between mean annual chl a concentrations in the uppermost $0.5 \mathrm{~cm}$ sediment layer and annual primary production.

Acknowledgements. L. A. H. Venekamp, M. Rademaker and W. Haver are acknowledged for their help in sampling and analysis, and W. Haver for stimulating discussions. J. Mulder (Department of Statistical Advice, Nijmegen University) is acknowledged for the application of statistical tests and for processing part of the data. R. Jungcurt drew the figures.
Admiraal, W. (1984). The ecology of estuarine sedimentinhabiting diatoms. In: Round, F. E., Chapman, D. J. (eds.) Progress in phycological research, Vol. 3. Biopress, Bristol, p. $269-322$

Admiraal, W., Bouwman, L. A., Hoekstra, L., Romeyn, K. (1983). Qualitative and quantitative interactions between microphytobenthos and herbivorous meiofauna on a brackish intertidal mudflat. Int. Revue ges. Hydrobiol. 68 : $175-191$

Admiraal, W., Peletier, H. (1979). Influence of organic compounds and light limitation on the growth rate of estuarine benthic diatoms. Br. Phycol. J. 14: 197-206

Admiraal, W., Peletier, H. (1980). Influence of seasonal variations of temperature and light on the growth rate of cultures and natural populations of intertidal diatoms. Mar. Ecol. Prog. Ser. 2: 35-43

Admiraal, W., van Arkel, M. A., Baretta, J. W., Colijn, F., Ebenhöh, W., de Jonge, V. N., Kop, A., Ruardij, P., Schröder, H. G. J. (1988). The construction of the benthic submodel. In: Baretta, J., Ruardij, P. (eds.) Tidal flat estuaries. Simulation and analysis of the Ems estuary. Ecological Studies 71, Springer-Verlag, Heidelberg, p. 105-152

Baillie, P. W. (1987). Diatom size distributions and community stratification in estuarine intertidal sediments. Estuar. coast. Shelf Sci. 25: 193-209

Banse, K. (1977). Determining the carbon-to-chlorophyll ratio of natural phytoplankton. Mar. Biol. 41: 199-212

Baretta, J., Ruardij, P. (eds.) (1988). Tidal flat estuaries. Simulation and analysis of the Ems estuary. Ecological Studies 71, Springer-Verlag, Heidelberg

Cadeé, G. C., Hegeman, J. (1974). Primary production of the benthic microflora living on tidal flats in the Dutch Wadden Sea. Neth. J. Sea Res. 8: 260-291

Colijn, F. (1982). Light absorption in the waters of the EmsDollard estuary and its consequences for the growth of phytoplankton and microphytobenthos. Neth. J. Sea Res. 15: $196-216$

Colijn, F. (1983). Primary production in the Ems-Dollard estuary. Ph.D thesis, University of Groningen.

Colijn, F., de Jonge, V. N. (1984). Primary production of microphytobenthos in the Ems-Dollard estuary. Mar. Ecol. Prog. Ser. 14: 185-196

Colijn, F., Dijkema, K. S. (1981). Species distribution of benthic diatoms and distribution of chlorophyll $a$ on an inter- 
tidal flat in the Dutch Wadden Sea. Mar. Ecol. Prog. Ser. 4 : 9-21

Daemen, E. A. M. J. (1985). Kwalificering en kwantificering van het microfytobenthos in de Oosterschelde. BALANS 1985-5 report (in Dutch)

de Jonge, V. N. (1979). Quantitative separation of benthic diatoms from sediments using density gradient centrifugation in the colloidal silica Ludox-TM. Mar. Biol. 51. $267-278$

de Jonge, V. N. (1980). Fluctuations in the organic carbon to chlorophyll a ratios for estuarine benthic diatom populations. Mar. Ecol. Prog. Ser. 2: 345-353

de Jonge, V. N. (1985). The occurrence of 'epipsammic' diatom populations: a result of interaction between physical sorting of sediment and certain properties of diatom species. Estuar. coast. Shelf Sci. 21: 607-622

de Jonge, V. N. (1988). The abiotic environment. In: Baretta, J., Ruardij, P. (eds.) Tidal flat estuaries. Simulation and analysis of the Ems estuary. Ecological Studies 71, Springer-Verlag, Heidelberg, p. 14-27

de Jonge, V. N. (1992a). Tidal flow and residual flow in the Ems estuary. Estuar. coast. Shelf Sci. 34: 1-22

de Jonge, V. N. (1992b). Physical processes and dynamics of microphytobenthos in the Ems estuary (The Netherlands).

- Ph.D. thesis, University of Groningen

de Jonge, V. N. (in press). Wind driven tidal and annual gross transport of mud and microphytobenthos in the Ems estuary and its importance for the ecosystem. In: Dyer, K. R., D'Elia, C. F. (eds.) Changing fluxes to estuaries: implications from science to management. International Symposium Series, Olsen \& Olsen, Fredensborg

de Jonge, V. N., van Beusekom, J. E. E. (1992). Contribution of resuspended microphytobenthos to total phytoplankton in the Ems estuary and its possible role for grazers. Neth. J Sea Res. 30: 91-105

Eaton, J. W., Moss, B. (1966). The estimation of numbers and pigment content in epipelic algal populations. Limnol. Oceanogr. 11: 584-595

Fenchel, T., Staarup, B. J (1971). Vertical distribution of photosynthetic pigments and the penetration of light in marine sediments. Oikos 22: 172-182

Gould, D. M., Gallagher, E. D. (1990). Field measurement of specific growth rate, biomass, and primary production of benthic diatoms of Savin Hill Cove, Boston. Limnol. Oceanogr. 35: 1757-1770

Hopkins, J. T. (1963). A study of the diatoms of the Ouse estuary, Sussex. The movement of the mudflat diatoms in response to some chemical and physical changes. J. mar. biol. Ass. U.K. 43: 653-663

Joint, I. R. (1981). Growth and survival of estuarine microalgae. In: Jones, N. V., Wolff, W. J (eds.) Feeding and sur-

This article was submitted to the editor vival strategies of estuarine organisms. Marine Science Series No. 15, Plenum Press, New York

Leach, J. H. (1970). Epibenthic algal production in an intertidal mudflat. Limnol. Oceanogr. 15: 514-521

Lorenzen, C. J. (1967). Determination of chlorophyll and pheopigments: spectrophotometric equations. Limnol. Oceanogr. 12: $343-346$

Ludden, E., Admiraal, W., Colijn, F. (1985). Cycling of carbon and oxygen in layers of marine microphytes; a simulation model and its eco-physiological implications. Oecologia 66: $50-59$

Moed, J. R., Hallegraeff, G. M. (1978). Some problems in the estimation of chlorophyll $a$ and pheopigments from preand post-acidification spectrophotometric measurements. Int. Revue ges. Hydrobiol. 63: 787-800

Montagna, P. A. (1984). In situ measurement of meiobenthic grazing rates on sediment bacteria and edaphic diatoms. Mar. Ecol. Prog. Ser. 18: 119-130

Moul, E. T., Mason, D. (1957). Study of diatom populations on sand and mudflats in the Woods Hole area. Biol. Bull. 113 351

Mullin, M. M., Sloan, P. R., Eppley, R. W. (1966). Relationship between carbon content, cell volume and area in phytoplankton. Limnol. Oceanogr. 11: 307-311

Pamatmat, M. M. (1968). Ecology and metabolism of a benthic community on an intertidal sandflat. Int. Revue ges. Hydrobiol. Hydrogr. 53: 211-298

Redalje, D. G. (1983). Phytoplankton carbon biomass and specific growth rates determined with the labeled chlorophyll a technique. Mar. Ecol. Prog. Ser. 11: 217-225

Redalje, D. G., Laws, E. A. (1981). A new method for estimating phytoplankton growth rates and carbon biomass. Mar. Biol. 62: 73-79

Riaux-Gobin, C., Llewellyn, C. A., Klein, B. (1987). Microphytobenthos from two subtidal sediments from North Brittany. II. Variations of pigment compositions and concentrations determined by HPLC and conventional techniques. Mar. Ecol. Prog. Ser. 40: 275-283

Steele, J. H., Baird, I. E. (1968). Production ecology of a sandy beach. Limnol. Oceanogr. 13: 14-25

Strathmann, R. R. (1967). Estimating the organic carbon content of phytoplankton from cell volume or plasma volume. Limnol. Oceanogr. 12: 411-418

Taylor, R. W., Gebelein, C. D. (1966). Plant pigments and light penetration in intertidal sediments. Helgoländer wiss. Meeresunters. 13: 229-237

van den Hoek, C., Admiraal, W., Colijn, F., de Jonge, V. N. (1979). The role of algae and seagrasses in the ecosystem of the Wadden Sea: a review. In: Wolff, W. J. (ed.) Flora and vegetation of the Wadden Sea. Stichting Veth, Leiden, p. $9-118$

Manuscript first received: April 2, 1992

Revised version accepted: October 15, 1993 